\title{
Contextualizing Dependency Syndrome in International Disaster Management: Support from Sen's Capability-Based Approach
}

\author{
Liza Ireni-Saban, Ph.D* \\ Lauder School of Government, Diplomacy and Strategy Interdisciplinary Center (IDC) Herzliya, Israel \\ *Corresponding Author: Liza Ireni-Saban, Lauder School of Government, Diplomacy and Strategy \\ Interdisciplinary Center (IDC) Herzliya, Israel
}

\begin{abstract}
During acute risks to survival, international aid agencies often face the dilemma that continued provision of relief can lead to continued dependency syndrome, in which relief undermines local capacities. This article aims to apply capability-based approach in international disaster management to meet international aid distributive implications in times of disasters. The paper suggests that Sen's basic tenets of capability-based distributive theory address the important ways in which disaster relief aid should be distributed to allow local communities and NGOs to rely on their own capacities to survive and recover from disaster.
\end{abstract}

Keywords: international aid, inequality, Amartya Sen, global distributive justice, disaster management.

\section{INTRODUCTION}

On April 24, 2015 a devastating earthquake of magnitude 7.8 on the Richter scale shocked Nepal. With an estimated 8 million people affected and more than 7,000 fatalities and 2.8 million people displaced, the estimated cost of reconstruction stood at more than $\$ 5$ billion. ${ }^{1}$ The Nepal government faced swift international aid: the Asian Development Bank donated $\$ 3$ million for immediate relief and pledged \$200 million for rehabilitation. The UN appealed for \$15 million to contribute to Nepal's reconstruction and USAID senta Disaster Assistance Response Team (DART) to the region pledging $\$ 10$ million for disaster relief. $^{2}$ Despite the enormous influx of international aid, the aftermath of the earthquake has left Nepal extremely dependent on foreign aid. ${ }^{3}$ Nepal's earthquake raises ethical concerns regarding international aid distribution in times of emergency.

Emergency situations including natural disasters demand immediate response, which differs from international aid granted for sustainable improvement in living standards in less developed countries. For that, the unusualness and urgency of large-scale disasters often entail independence from affected governments that are overwhelmed by the magnitude of the disaster and are unable to meet the needs of their citizens. The effectiveness of relief aid depends on how and for what it is used. The ethical dilemma arises when foreign aid in disaster settings may encourage dependency, undermining government agencies' and civil society organizations' disaster relief capacities. While it is not always true that relief aid in an emergency encourages dependency, challenges towards effective international aid distribution require an appropriate normative framework that goes beyond disaster management to broader aspects of global distributive justice (Fukuda-Parr, 2011).

This article questions whether normative acceptable frameworks of aid distribution should inform the distribution of international aid in urgent states of affairs. Insofar as one endorses features of global distributive schemes, emergency situations are claimed to be morally relevant to international aid distribution. ${ }^{4}$ While global distributive justice theories share the idea that international aid should not exacerbate vulnerability and stigmatization by reinforcing existing inequalities and ongoing exploitive regimes, it is suggested that the focus should be on opportunities and capabilities that affected

\footnotetext{
${ }^{1} 2015$ Nepal Earthquake, Event Recap Report September 2015. http://thoughtleadership.aonbenfield.com/ documents/201509-nepal-earthquake.pdf

${ }^{2}$ Nepal Earthquake - Fact Sheet \#2, USAID, 27 April 2015.

${ }^{3} \mathrm{http} / / / \mathrm{www}$.unocha.org/cerf/resources/top-stories/nepal-cerf-allocates-15-million-emergency-response

${ }^{4}$ On the distinction between emergency and development aid, see Rubenstein (2007).
} 
communities and individuals have to pursue the things that they perceive as valuable. For assessing disaster affected countries' dependency we draw on Amartya Sen's analysis of the capability approach to global distributive justice, allowing for a wider scope of justice by emphasizing the role of aid recipients in carrying out their own relief efforts to increase their capacity to cope with extreme events. (Nair, 2018)

The subsequent sections aim to provide some clarity about the term dependency syndrome when used within the field of international disaster management through the lens of Amartya Sen's capability-based approach to global distributive justice.

\section{DEPENDENCY IN NORMAL VERSUS DEPENDENCY IN EMERGENCY SiTUATIONS}

Dependency is assumed to be one of the constitutive features for the existence of any human community. As stated by Dean $(2004,194)$ :

Interdependency is an essential feature of the human life course and the human condition. One might argue that it is constitutive of our humanity and the achievement of human identity. This is neither new nor radical. It is captured for example, in the timeless aphorism attributed to the Xhosa people of South Africa - "A person is a person through other persons". Personhood is founded in and through dependency on other persons.

As such, dependency is necessary to shape a system of rights and responsibilities based on the rationale of caring for others' needs. This definition delivers the message that dependency should be evaluated by how it expands human development in terms of social, economic, political, and human rights. The use of "dependency" as a normative framework for evaluating and assessing human wellbeing raises questions about social justice, and distributive justice in particular.

In the context of international aid, Lensink and White(1999) offer to define international aid dependence as follows: "A country is aid dependent if it will not achieve objective $\mathrm{X}$ in the absence of aid for the foreseeable future." Aid dependency, when considered from the perspective of Lensink and White, tends to focus on the idea that external aid should not necessarily lead to "wrongdoings" and that countries that rely on high levels of aid regardless of whether they make progress toward some development objective should not be regarded as "dependent" on the aid for achieving their development objectives. At the same time, Lensink and White came up with a short list of "aid dependent", namely developing, countries where aid remains an ineffective mechanism for meeting development objectives. Yet, this argument does not help to explain the widely held suspicion that aid dependency in the context of international aid has negative moral and social connotations "Dependence is decadent - its byproducts are laziness and degeneration, poverty and crime. It is a way of life transmitted to the young, generating cycles of dependency. Dependency justifies, even compels, negative judgments." (Fineman, 2001). Thus, the unintended consequences of dependency are reflected in the categorization of individuals and groups as dependent and vulnerable, which often becomes highly politicized, leading to stigmatization of those groups (e.g., single mothers, elderly, ethnic minorities).

Following Roger Riddell and Rehman Sobhan, the negative effects of aid dependence should be considered within "that process by which the continued provision of aid appears to be making no significant contribution to the achievement of self-sustaining development" $(1996,24)$. Central to these perceptions is that reliance on international aid would be a bad thing, creating disincentive effects on recipient societies that undermine community- or individual-based initiatives or competencies. (Wood and Sullivan, 2015) Others hold that foreign aid dependence may be regarded as a coping mechanism by active rather than passive recipients of aid that enables people to maintain their livelihoods and prevents a slide into destitution (Ellis, 2000). This perspective of international aid dependency is admittedly more complex and multifaceted: it means that how international aid is distributed is weighty when it allows greater opportunities to convert material assets into capabilities:

Adjustments to high levels of aid over a number of years are all part of what is often referred to as "aid dependence". A dependence on high aid inflows is not necessarily a bad thing. If the aid is used productively to promote social and economic progress, its net effect is likely to be highly positive for development in the country receiving the aid. But where the aid is 
ineffective, it is important to consider the potential negative effects of that aid (Lancaster, 1999, 494).

This approach has led development economists and policy makers such as Paul Streeten, France Stewart, and Mahbub ul Haq to establish an international development program that draws on the unique insights of the capabilities approach to aid distribution as its main tenets (Gasper, 1999; Sen, 2000; Streeten, Burki, ul Haq, Hicks, and Stewart, 1981). The basic needs approach (BNA) program aimed at providing a positive aspect of aid dependency by drawing on a broader sense of human wellbeing: "The objective of a basic needs approach to development is to provide opportunities for the full physical, mental, and social development of the individual." (Streeten, 1979,136). The BNA suggests that a society cannot be defined as developed unless it offers the opportunity for all its citizens to improve citizens' freedom. Thus, the BNA interprets basic needs as means rather than ends in extending opportunities of valuable functionings. ${ }^{5}$

In emergencies, dependency is usually treated as a cluster of negative aspects of humanitarian relief and something to be avoided. Dependency syndrome is used in the context of emergencies to capture the way disaster relief and response aid manifest as a coincident pattern associated with ambiguous societal conditions that result from the reliance of the disaster-affected population (receivers) on humanitarian aid and on its providers (Deveaux, 2013).Dependency syndrome often directs attention to a seeming gapin aid distribution perceptions, namely between disaster-affected communities' subsistence needs, and those communities' perception of the role of the aid agency. This can sometimes lead to continuing reliance on international aid actors to meet citizens' needs while ignoring or side-lining state response and relief capacities. The need for continued provision of relief during the aftermath of a disaster is seen as the problem, rather than a symptom of poverty, destitution, or local conflict that intensified in extreme events. However, in situations where disaster overwhelms local capacities, cutting back relief resources and services will limit access to basic welfare and increase disaster vulnerability. Thus, the focus of the discourse around dependency in international disaster management should not be centred on avoiding dependence on emergency relief, but rather on prioritizing aid distribution in a way that expands the possibilities and capacities of disaster-affected communities. The following sectionsdevelop a fuller account of how capability approach could be implemented in international disaster management with distributive aspects.

\section{Materials ANd Methods}

In this article, we conceptualize distributive justice judgments as complex evaluations whereby several principles of justice and social resources are considered simultaneously. Our main aim is to unveil the structure of distributive justice judgments, using this facet approach as a formal framework for expressing the multi-dimensionality of distributive justice judgments (Borg and Lingoes, 1987; Borg and Shye, 1995). Distributive justice theories can be constructed with diverse levels of analysis, including distributive good, community of justice, preconditions of distribution, the structure of principles and rules, and their content. An extended framework for the analysis of the multiplicity of conceptions of distributive justice includes questions such as: What is to be distributed? Among whom are advantages and disadvantages to be divided (community of justice)? What are the preconditions for (re)distribution? What is the structure of the principle of distribution? What is the content of the principle of distribution?

Thus, in approaching the issue of the units of analysis, first we must understand the structure of distributive justice. In Figure 1 distributive justice is depicted as having multiple layers. Each layer consists of a distributive justice domain, which, in turn, comprises policy issues in which different kinds of relationships exist among policy actors. The distributive justice domain can be defined as a substructure identified by specifying a substantively defined criterion to examine the affinities and contrasts of distributive justice judgments in an effort to resolve the ethical dilemmas faced by the international disaster management community.

\footnotetext{
${ }^{5}$ Functionings, in terms of Sen's capability theory, refer to what constitute life or well-being value including work, pleasure time, education, health, sense of respect, and being a member of a community. Such conceptualization demarcates the distinction between means and functionings, in that the former includes goods and services that enable the functionings, and the whole social and institutional context has an impact on the conversion factors of means to functionings.
} 


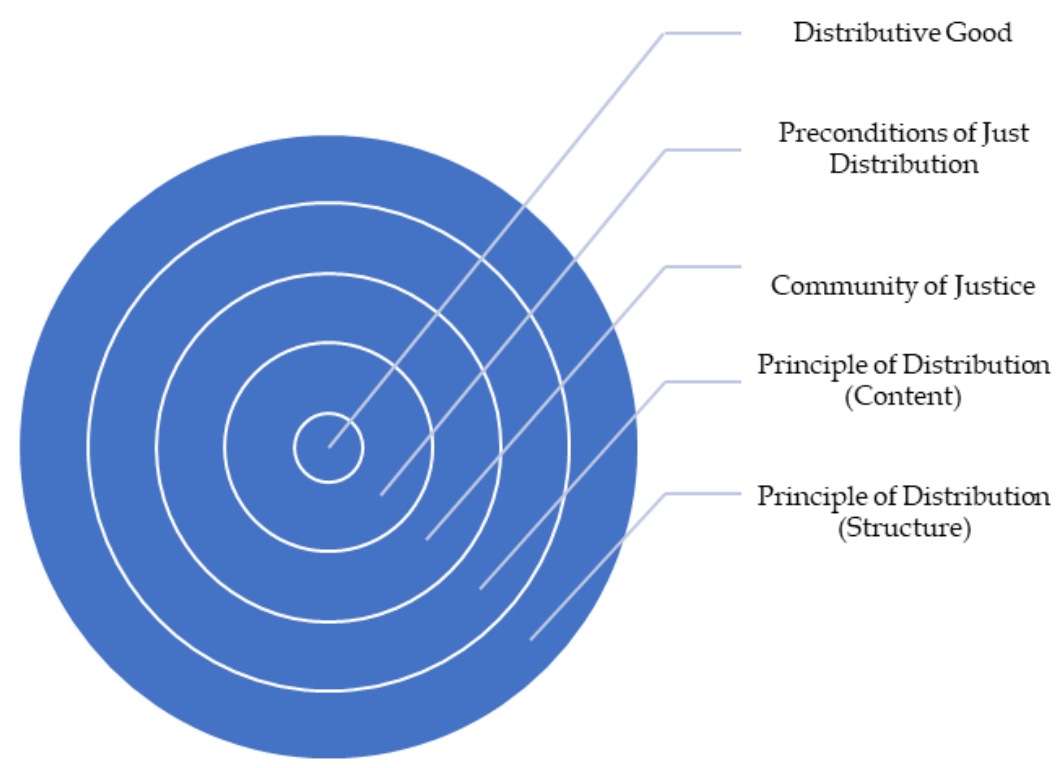

Figure1: Multi-layers of Distributive Justice Evaluation

The following section outlines the capacities approach to global distributive justice, based on Amartya Sen's work. Amartya Sen, winner of the 1998 Nobel Prize in Economic Sciences, insisted that distributive justice is connected to underlying social-economic and political structures and their roles in controlling individual capacities.(Burchardt and Hick,2018)Sen stresses the idea that the application of capability approach in vulnerability and risk theory shouldnot be reducible to the amount of resources an individual has at his own disposal but rather to an individual's personal competencies, resources influenced by his social and material environment.

\section{Facet analysis of Sen's Capability Approach to Global Distributive Justice in DISASTER MANAGEMENT}

\subsection{What is Distributed?}

Amartya Sen's theory offers to assess the kind of distributed goods in terms of human capabilities. According to Sen, a theory of primary goods must take into consideration not only of the primary goods the persons respectively hold, but also of the relevant personal characteristics that govern the conversion of primary goods into the person's ability to promote her ends. What matters to people is that they are able to achieve actual functionings, that is the actual living that people manage to achieve (Sen, 1999, 74).

The idea of functioning refers to anything a person could do or be, it "reflects the various things a person may value doing or being, varying from the basic (being adequately nourished) to the very complex (being able to take part in the life of the community)" (Sen, 1999,75). If we want to make interpersonal comparisons of well-being, we should use a category that encompasses both certain functionings and the capability to choose the attainment of such functionings, that is, "the freedom to achieve actual livings that one can have a reason to value" (Sen, 1999, 73). Thus, Sen links capabilities not functioning with a liberal respect for individual freedom and also with an appropriate demand for individual responsibility: "In dealing with responsible adults, it is more appropriate to see the claims of individual on the society in terms of freedom to achieve rather than actual achievements." (Sen, 1992, 148). ${ }^{6}$

\footnotetext{
${ }^{6}$ Sen rejects the need to constitute a lexical list of relevant capabilities as there is a problem in determining the relative weights and value of the capabilities: "The judgement must take into account the extent to which the different abilities are being realised or violated. Also, the weighting must be contingent on circumstances. We may have to give priority to the ability to be well-nourished when people are dying of hunger in their homes, whereas the freedom to be sheltered may rightly receive more weight when people are in general well-fed, but lack shelter and protection from the elements." (Sen, 2005, 159).
} 
Dependency is assessed by the contribution that aid makes to people's livelihoods. In this sense, dependence on response and relief efforts is a mechanism to meet subsistence needs in times of largescale disaster. Response and relief efforts are regarded as the most visible disaster management function at the international level (Coppola, 2011). This phase includes those activities that directly address immediate needs of affected people, namely medical care, water and sanitation, food, and shelter (Tsunami Evaluation Coalition, 2006,26).

For example, at the outbreak of Typhoon Haiyan (also known as Yolanda) in the Philippines, the Philippines Government initiated a list of needed resources and services through the United Nations Office for the Coordination of Humanitarian Affairs (UNOCHA). The list included food, water, sanitation and hygiene kits, shelter, medicine, debris clearing, and logistics hubs to support the sustainable delivery of aid (UNOCHA, 2013).

By applying Sen's capability approach to global distributive justice, distributed goods should be regarded as means to enhance people's own capacities. It is assumed to reflect local capacities and internal competencies and dispositions that can be cultivated and facilitated by external aid and resources, but never provided by them (Sen, 1985). Viewed in this way, response and relief efforts should be distributed to the extent that does not undermine the affected community's autonomy and freedom to choose and to act as "greater freedom enhances the ability of people to help themselves and to influence the world" (Sen, 1999,18).Based on Sen's framing, the concept of dependency is attentive to the moral demands of the affected communities and individuals that are impeded from acquiring basic capabilities and meet their subsistence needs because of disasters. Disaster risk and vulnerability indicators often consist of basic needs operationally including food, water, shelter, and hospital beds during a disaster event. Sen is correctly concerned that these goods will be viewed as only "minimal needs", that only physical needs are what counted rather than as opportunities for other valuable functionings. Focusing on "basic needs and nothing more" lends itself to down-sizing wellbeing and moral responsibilities (Sen, 1984,515).

\subsection{Community of Justice}

Sen demarcates the boundaries of community of justice by referring to personal heterogeneities to indicate the variation among individuals in ability to convert resources into functionings. (Srinivasan, 2007) According to Sen:

People have disparate physical characteristics connected with disability, illness, age or gender, and these make their needs diverse. For example, an ill person may need more income to fight her illness-income that a person without such an illness would not need ... A disabled person may need some prosthesis, an older person more support and help, a pregnant woman more nutritional intake, and so on $(1999,70)$.

Sen links these opportunities to the perspective of freedom; it makes the idea of personal heterogeneities more inclusive and thus demands that the viewpoints of others, whether or not belonging to some group of which one is conceived as a member, receive appropriate attention. This opens the way to make assessments of people's state of existence in terms of people's actual doings and beings that people are able to choose $(2009,130)$.

In extreme events that often overwhelm the ability of people to meet their subsistence needs, international aid agencies must attempt to assess the vulnerability of affected individuals, groups, communities, and country in order to effectively address the victims' needs with their response services and resources. Dependency can be determined by establishing vulnerability criteria of relief recipients. As seen, Sen establishes the boundaries of community of justice by drawing on the criterion of functioning. From this perspective, Sen provides an assessment of members of the community of justice in terms of people's actual doings and beings (Sen, 2000, 24-25). Within the context of dependency on relief assistance, certain groups in society such as women, children, and elderly may face different types of vulnerabilities and so may be dependent in different ways on external relief assistance.

Thus, international disaster relief agencies need to gain meaningful knowledge of local communities and assist affected communities to articulate their needs in a way that enables relief agencies to act on them (Ireni-Saban, 2014). If not done, evaluations of vulnerable people may not meet objective need 
assessment measures of services precisely because they do not include the interpersonal aspect of service delivery so critical to the end user. It is then possible to move away from the negative aspects of dependency by assuming a positive role of international disaster relief agencies to treat local communities as more active, rather than passive, recipients of assistance, and to provide opportunities to change social relations.

One of the successful initiatives to empower Qiang women and peasants' communities in Sichuan province was set in the aftermath of 2008 Sichuan earthquake in China. The project's main achievementlies in the employment of a top-down structure in day-to-day life for people and communities with women, homeless, and peasants (Ireni-Saban, 2014).The community of Qiang women in the Maoxian County of Sichuan was left behind as their husbands and sons have left the rural villages to become migrant workers in China's major coastal cities. The earthquake had devastating effects on these women, increasing their stress and loneliness, leaving Qiang women and single-mother families extremely vulnerable. In order to help the earthquake-affected Qiang women the Asian Foundation-China, together with other Sichuan Administration support, implemented community capacity-building activities including strengthening their mutual-assistance and networking capacity, and enhancing their participation in social life and long-term community development to fully include this community of homeless and isolated Qiang women(Give2Asia, 2009).

Such activities illustrate Sen's upholding the need for reorientation of the institutional approach from one of providing goods and services to passive recipients to a BNA one that provides countries with genuine opportunities to dictate their development track:

The ends and means of development call for placing the perspective of freedom at the center of the stage. The people have to be seen, in this perspective, as being actively involved given the opportunity - in shaping their own destiny, and not just as passive recipients of the fruits of cunning development programs $(1999,53)$.

Thus, following the BNA approach, Sen insists on distribution of actual freedoms rather than commodities: "The actual freedoms enjoyed by different persons - persons with possibly divergent objectives - to lead different lives that they can have reason to value." $(1990,114)$.

\subsection{Preconditions of Just Distribution}

For Sen, the device of the impartial spectator helps to deliberate from the perspective of a "spectator" at a distance (2009). Sen rejects the criterion of preference as a precondition for distributive justice. ${ }^{7}$ Sen draws on the notion of adaptive preferences to denote the circumstances of economic constraints and socially repressive traditions that influence the person's preferences or perceptions of satisfaction with his/her state of being as he tends to adapt his desires to what is viable. Thus, preferences depend on social arrangements; for example, gender biases such as making female secondary to male have influence on the intra-family distribution of food and health care (Sen, 1999,126). However, in a society where the conditions under distributive justice ensure basic capabilities to substantive freedoms, rather than preferences shaped by an acceptance of a given order or unjust background conditions, "enhance the ability of people to help themselves and to influence the world" (Sen, 1999,18)

Sen admits that there are economic and social conditions that may not encourage people's critical assessment or ability to question their preferences and interests (Sen, 2000, 24). Drawing on the preconditions of justice, Sen might agree at some point that dependency on international relief agencies leads to tension between governments and relief agencies and the desire of relief agencies to gain control over the delivery of their resources. For that, it is necessary to promote greater levels of local transparency and accountability to beneficiaries so that aid recipients know what they are entitled to and how likely it is to be provided.

A recent example of the likelihood of disaster relief assistance embedded in exploitive structures can be found in the case of the Haiti earthquake. On January 12, 2010, Haiti faced a 7.0 magnitude

\footnotetext{
${ }^{7}$ While the utilitarian approach takes into account mental attitudes of people, Sen's capabilities approach refers more to the assessment of people's state of existence in terms of actual functionings (1999).
} 
earthquake, which caused the death of 100,000-160,000 and massive damage to infrastructures such as hospitals; air, sea, and land transportation; and communication systems. At the outbreak of the earthquake, due to widespread devastation and damage throughout Port-au-Prince and elsewhere to infrastructure, food supply lines were down. Foreign food aid agencies immediately mobilized provisional needs for the earthquake-affected population. Between January and June 2010, USAID sent 214,000 metric tons of food aid to Haiti (USAID, 2010,15). Irregularity in the distribution of food aid led to price fluctuations of basic commodities especially rice, hindering the ability of miniwholesalers at the local level to buy rice to sell to consumers. The large amount of food aid depressed commodity prices and resulted in lower income of Haitian corn producers and farmers. Foreign food aid forced Haitian entrepreneurs out of market competition (Webster, 2012). The main concern therefore is not dependency per se, but the way in which dependency is structured, namely by causing disincentives for local producers and farmers. Haitian people did not question acceptance of the trade relationship with the United States, given the fact that Haitians became used to living in difficult social and economic circumstances. In terms of Sen's view of adaptive preferences, dependency can be referred to as the mental state of coming to terms with and accepting aninferior position as an effect of an adverse social and economic environment that influences the society's perception (Sen,1999,126-127).

The influx of donated rice following the Haiti earthquake demonstrates the unequal trade relations between Haiti and the United States, but also the perception of interests and who deserves what, which had an influence on Haiti's dependency on continuing food aid. During the 1980s, Haiti was a self-sufficient rice producer. However, President Clinton, who was then nominated as UN Special Envoy to Haiti, developed a close relationship with Haitian President Jean Bertrand Aristide. This relationship paved the way for American rice exporters' access into the Haitian local market (Webster, 2012). By 1994, two years after Clinton's nomination, American Rice Inc. was already netting $\$ 373$ million in rice sales annually (Chavla, 2010; Kenny, 2011). In 2010, Clinton apologized for the negative implication of his policy, which resulted in a reduction of rice consumed in Haiti from 47 to 15 percent of rice supply. ${ }^{8}$

American industry has actually benefited from the influx of donated rice in the aftermath of the disaster: "Haiti is even more awash in rice while American agribusiness makes billions of dollars every year through generous government subsidies." (Webster, 2012).

It is suggested that Sen's view on adaptive preferences strives for greater freedom, which promotes the ability of people to help themselves insofar as they will finally be able to leave their adaptation behind and choose whatever they value to be and to do (Sen, 1999).

\subsection{The Principle of Distribution (Content)}

Sen urges that the principle of distributive justice should allow everyone in the society to enjoy freedom. The rationale of sufficientarianism behind Sen's principle of justice requires basic capability equality - policies and actions should be pursued so that each person equally has freedom to attain a sufficient level of basic capabilities. However, Sen is less explicit about the extent of freedom a society should promise to its members such as whether it is the duty of the society to assist people to reach every goal they value by economic rearrangements. Sen does not explain exactly how to rank the order of different functionings and hence different capabilities to achieve functionings as the measurement of well-being, but remarks that "economic unfreedom, in the form of extreme poverty, can make a person a helpless prey in the violation of other kinds of freedom" (Sen, 1999, 8).

Sen's principle of justice requires basic capability equality - policies and actions should be pursued so that each person equally has freedom to attain a sufficient level of basic capabilities. Sen's distributive principle, which stresses some degrees of freedom and autonomy as well as needs of health, food, and shelter, leads to a realistic chance of integrating disaster relief and development objectives by allowing local communities and NGOs to exercise their capability for deliberation and informal safety nets and support in the face of a disaster event. In the wake of the Katrina disaster, the Neighbourhood Partnership Network (NPM), a non-profit organization, functions as a citywide network of

\footnotetext{
${ }^{8}$ Bill Clinton in testimony before the Senate Foreign Relations Committee. http://www.democracynow.org/2010 /4/1/clinton_rice
} 
neighbourhoods in New Orleans (Ireni-Saban, 2014).The network aims at utilizing neighbourhood collaboration necessary to increase access to decision making at government level to include the voices of affected individuals and communities across New Orleans. This organization motivates New Orleans's citizens to become actively involved in the formal decision-making processes that impact quality-of-life issues raised in neighbourhood rebuilding and civic processes for both individuals and communities.

\subsection{The Principle of Distribution (Structure)}

Sen offers to broaden the universal impartial evaluative basis to include an "open impartiality", which according to Sen, is "the procedure of making impartial assessments" that invokes judgments both from within and from without any given community, seeking to identify the "disinterested judgments of "any fair and impartial spectator" (Sen, 2009, 123). 9 Sen's notion of "open impartiality" incorporates two aspects to the meaning of "open". One aspect is associated with the need to distance oneself from any particular position to ensure being "open" to considerations from anyone; the second aspect concerns the epistemological conditions that are required of disinterested judgment about justice and its demands by a subject (evaluator) (Sen, 2009,128). This structure allows taking into account all the arguments and counterarguments by the "eyes of mankind" (Sen, 2009, 130) as "positional objectivity". Sen's conception of capability explicitly focuses on "positions" that are not easily exchangeable relative to alternative social rules. Rather, each individual, in as much as she will be an "object" (recipient) of social rules, is expected to provide information as the "subject" (evaluator) of social rules about such particularities, being a witness or an expert of those characteristics or experiences that cause different kinds of disadvantages.

The plural grounding of the principle that should inform the distribution of international aid ensures open impartiality, as deliberations of justice at the community level should be represented and recognized:

Assessment of justice demands engagement with the "eyes of mankind", first, because we may variously identify with the others elsewhere and not just with our local community; second, because our choices and actions may affect the lives of others far as well as near; and third, because what they see from their respective perspectives of history and geography may help us to overcome our own parochialism (Sen, 2009, 130).

This structure establishes cooperative forms of responsibility and solidarity. Sen's theory is likely to entail a parochial view so that international aid will arise in the course of an ongoing relationship with aid recipients in emergency situations rather than in development contexts. This structure of distributive principle would force international donors to deliberate the effects of international aid on the recipient country.

\section{CONCLUSiOnS}

Addressing the distributive concerns of the effectiveness of disaster aid and relief efforts has almost exclusively focused on economic evaluation of disaster affected countries. This paper draws on capability-based approach to international disaster management to meet the distributive aspects raised by dependency syndrome in disaster resilience evaluation. Sen's theory of distributive justice helps to frame concerns around dependency in times of natural disaster in terms of capabilities and freedom of affected individuals and communities to choose and act. Sen insists on respecting vulnerable people's need to use external aid to exercise a capability for deliberation. It is then suggested that Sen's theory of global distributive justice, despite some of its contentious claims, offers a useful starting point for reflections on how to devolve greater moral responsibility to aid recipients for the management of international relief aid. Tackling dependency in international disaster management should operate under the constraints of freedom and autonomy to allow local communities and NGOs to exercise their ability to establish an informal community support system in the face of a disaster event. The structure of interdependency helps to lessen the tension between disaster relief and development objectives. Cooperative forms of disaster relief aid delivery with greater respect for disaster-

\footnotetext{
${ }^{9}$ Sen draws the distinction between open and closed impartiality by associating closed impartiality to Rawls' original position. Closed impartiality does not ensure halting the prejudices of members of the focal group under a "veil of ignorance". See Sen, 2002, 447-448. See also, Robeyns, 2016.
} 
vulnerable people's needs assessment ought to encourage people who are dependent on external assistance to actively participate in disaster management rather than conceiving themselves as passive and vulnerable recipients.

Viewed from a capabilities approach, natural disaster events paradoxically create ahuge opportunity to build human and community capacity for self-reliance and sustainable well-being and prosperity, if efforts of constructive engagement take into consideration communities' knowledge, experience, and vision for development and recovery needs. For such initiatives to be effective in strengthening community self-reliance, they need to be guided by organizations that are committed to support communities' capacity for maintaining the network and informal ties necessary for immediate relief response.

\section{REFERENCES}

[1] Aldrich, D. (2010). "Fixing Recovery: Social Capital in Post Crisis Resilience."Journal of Homeland Security, June: 1-9.

[2] Archibugi, D.(2008). The Global Commonwealth of Citizens: Toward Cosmopolitan Democracy. Princeton, NJ: Princeton University Press.

[3] Barry, B. (1998). "International Society from a Cosmopolitan Perspective." In International Society: Diverse Ethical Perspectives, edited by D. R. Mapel and T. Nardin, 144-163. Princeton, NJ: Princeton University Press.

[4] Beitz, C. (2001). "Does Global Inequality Matter?”Metaphilosophy 32(1-2):95-112.

[5] Borg, I.,and Lingoes, J. C. (1987). Multidimensional Similarity Structure Analysis. New York: Springer.

[6] Borg, I.,and Shye, S. (1995). Facet Theory: Form and Content. Newbury Park, CA: Sage.

[7] Burchardt T. and Hick T. (2018) Inequality, Advantage and the Capability Approach. Journal of Human Development and Capabilities 19:1,38-52.

[8] Caney, S. (2005). "Cosmopolitan Justice, Responsibility, and Global Climate Change."Leiden Journal of International Law18:747-775.

[9] Chavla, L. (2010). "Bill Clinton's Heavy Hand on Haiti's Vulnerable Agricultural Economy: The American Rice Scandal."Council on Hemispheric Affairs, 14 April.

[10] Cherpitel, D. (2001). "Deadly Forces."The Guardian, 28 March.

[11] Coppola, D. P. (2011).Introduction to International Disaster Management, 2nd Edition. Oxford, UK: Elsevier/Butterworth-Heinemann.

[12] Dean, H.,ed.(2004). The Ethics of Welfare: Human Rights, Dependency and Responsibility. Bristol: The Polity Press.

[13] Deveaux, M. (2013). “The Global Poor as Agents of Justice.”Journal of Moral Philosophy 12(2):1-25.

[14] Drèze, J.,and Sen, A. (2002).India: Development and Participation. Oxford, UK: Oxford University Press.

[15] Ellis, F.(2000).Rural Livelihoods and Diversity in Developing Countries. Oxford, UK: Oxford University Press.

[16] Farmer, P.(2011).Haiti after the Earthquake. New York: Public Affairs.

[17] Fineman, M. (2001). "Dependencies.'In Women and Welfare: Theory and Practice in the United States and Europe, edited by N. Hirschmann, and U. Liebert, 23-37. New Brunswick, NJ: Rutgers University Press.

[18] Fukuda-Parr, S.(2011). "Theory and Policy in International Development: Human Development and Capability Approach and the Millennium Development Goals."International Studies Review 13(1): 122-132.

[19] Gasper, D. (1999). "Ethics and the Conduct of International Development Aid: Charity and Obligation."Forum for Development Studies26(1):23-57. Reprinted in Mervyn Frost,ed.,International Ethics. London, Delhi \& Los Angeles: Sage Publications.

[20] Give2Asia.(2009)."Sichuan Earthquake Relief and Recovery Following the May 12, 2008 Earthquake. Interim Report.” May.

[21] Heilbroner, R. L.(1987). "The Theory of Moral Sentiments." In The Essential Adam Smith, edited by R. L. Heilbroner, and L. J. Malone, 57-64. New York: W.W. Norton \& Company.

[22] Held, D. (1995). Democracy and the Global Order: From the Modern State to Cosmopolitan Governance. Cambridge, UK: Polity Press.

[23] Held, D. (2003). “Cosmopolitanism; Globalization Tamed?"Review of International Studies 29:465-480.

[24] Ireni-Saban, L.(2014).Disaster Emergency Management: The Emergence of Professional Help for Victims of Natural Disasters. Albany, NY: SUNY Press.

[25] Kenny, C.(2011).“Haiti Doesn't Need Your Old T-Shirt.”Foreign Policy 10 November. 
[26] Lancaster, C. (1999). “Aid Effectiveness in Africa: The Unfinished Agenda."Journal of African Economies 8(4):487-503.

[27] Lensink, R.,and White, H.(1999).Aid Dependence. Issues and Indicators. EGDI Study 1999:2, Stockholm: Ministry for Foreign Affairs.

[28] Levine, R.(2004).Millions Saved: Proven Successes in Global Health. Washington DC: Center for Global Development.

[29] Longstaff, P. H., Armstrong, N. J., Perrin, K., Parker, W. M., andHidek, W. A.(2010).“Building Resilient Communities: A Preliminary Framework for Assessment."Homeland Security Affairs 6(3):1-23.

[30] Nair T. (2018) Power, Capability and Cultural Subjects: An Inquiry into "Institutional Neglect" in Participatory Planning, Journal of Human Development and Capabilities, 19:3, 331-344

[31] Nussbaum, M.(2002). “Capabilities and Social Justice.”International Studies Review 4(2): 123-135.

[32] Nussbaum, M. C. (2003). "Capabilities as Fundamental Entitlements: Sen and SocialJustice." Feminist Economics 9(2-3):33-59.

[33] Pelling, M., and High, C.(2005).“Understanding Adaptation: What Can Social Capital Offer Assessment of Adaptive Capacity?" Global Environmental Change 15(4):308-319.

[34] Pogge T.(1994). “An Egalitarian Law of Peoples.”Philosophy and Public Affairs 23(3):195-224.

[35] Pogge T.(2002).World Poverty and Human Rights. Cambridge, UK: Polity Press.

[36] Pogge T. (2004). ““Assisting' the Global Poor.”In The Ethics of Assistance, edited by D. K. Chatterjee,260-288. Cambridge, UK: Cambridge University Press.

[37] Rawls, J. (1993). Political Liberalism. New York: Columbia University Press.

[38] Riddell, R.,andSobhan, R.(1996).Aid Dependency: Causes, Symptoms and Remedies. SIDA Project.

[39] Robeyns, I. (2006). “The Capability Approach in Practice.”Journal of Political Philosophy 14(3):351-376.

[40] Robeyns I.(2016) Capabilitarianism, Journal of Human Development and Capabilities, 17:3, 397-414

[41] Rubenstein, J. (2007). “Distribution and Emergency.”The Journal of Political Philosophy 15(3):296-320.

[42] Sen, A.(1984).Resources, Values, and Development. Cambridge, MA: Harvard University Press.

[43] Sen, A.(1985).Commodities and Capabilities. Amsterdam: North-Holland.

[44] Sen, A.(1990).“Justice: Means versus Freedom.”Philosophy \& Public Affairs 19:111-121.

[45] Sen, A.(1992). Inequality Reexamined. Cambridge, MA: Harvard University Press.

[46] Sen, A.(1999).Development as Freedom. New York: Oxford University Press.

[47] Sen, A.(2000)."The Standard of Living."InTheStandard of Living: The Tanner Lectures: Cambridge, 1985, edited by A. Sen, J. Muellbauer, R. Kanbur, K. Hart, and B. Williams,20-38. Cambridge, UK: Cambridge University Press.

[48] Sen, A.(2002). “Open and Closed Impartiality.”The Journal of Philosophy 99(9):445-469.

[49] Sen, A.(2005). "Human Rights and Capabilities."Journal of Human Development 6(2):151-166.

[50] Sen, A.(2009).The Idea of Justice. Cambridge, MA: Harvard University Press.

[51] Shaw, B. J.(2005)."Rawls, Kant's Doctrine of Right, and Global Distributive Justice.”The Journal of Politics 67(1):220-249.

[52] Srinivasan S. (2007) No Democracy without Justice: Political Freedom in Amartya Sen's Capability Approach, Journal of Human Development and Capabilities, 8:3, 457-480

[53] Streeten, P. P.(1979).“Basic Needs: Premises and Promises.”Journal of Policy Modeling 1:136-146.

[54] Streeten, P. P., Burki, S. J., ul Haq, M., Hicks, N., and Stewart, F. (1981). First Things First, Meeting Basic Human Needs in Developing Countries. Oxford, UK and New York: Oxford University Press.

[55] Tan, K.-C.(2004). Cosmopolitanism, Nationalism and Patriotism. Cambridge, UK: Cambridge University Press.

[56] Thorburn, C. 2007. "The Acehnese Gampong Three Years On: Assessing Local Capacity \& Reconstruction in Post-Tsunami Aceh. Report of the Aceh Community Assistance Research Project (ACARP)."http://www.indo.ausaid.gov.au/featurestories/acarpreport.pdf

[57] Tsunami Evaluation Coalition.(2006).Coordination of International Humanitarian Assistance in TsunamiAffected Countries. July.

[58] UNDP (United Nations Development Programme). (2005). Civil Society in Aceh: An Assessment of Needs to Build Capacity to Support Community Recovery. New York: UN.

[59] UNOCHA.(2013).“Philippines: Typhoon Haiyan Action Plan - November 2013.”http://www.unocha.org/ cap/appeals/philippines-typhoon-haiyan-action-plan-november-2013 
Contextualizing Dependency Syndrome in International Disaster Management: Support from Sen's Capability-Based Approach

[60] USAID. U.S. Agency for International Development.(2010).USAID Office of Food for Peace Haiti Market Analysis. August.

[61] van Hooft, S. (2009). Cosmopolitanism: A Philosophy for Global Ethics. Stocksfield: Acumen.

[62] Webster, D.(2012).Fault Line: Aid, Politics, and Blame in Post-Quake Haiti: Two Years After the Earthquake, Where did the Money Go? Global Post. http://www.globalpost.com/dispatch/news/regions/ americas/haiti/120110/haitiearthquake-aid-rice

[63] Wood, R. M.,and Sullivan, C.(2015)."Doing Harm by Doing Good? The Negative Externalities of Humanitarian Aid Provision during Civil Conflict.”The Journal of Politics 77(3):736-748.

Citation: Liza Ireni-Saban, Ph.D. "Contextualizing Dependency Syndrome in International Disaster Management: Support from Sen's Capability-Based Approach” International Journal of Political Science (IJPS), vol 5, no.3, 2019, pp. 49-59. doi: http://dx.doi.org/ 10.20431/2454-9452.0503004.

Copyright: (C) 2019 Authors. This is an open-access article distributed under the terms of the Creative Commons Attribution License, which permits unrestricted use, distribution, and reproduction in any medium, provided the original author and source are credited. 